\title{
A televisão e a prática do zapping: interatividade com a audiência
}

\section{Roseane Andrelo}

Jornalista e mestra em Comunicação pela Unesp/Bauru, doutoranda em Educação Escolar pela Unesp/Araraquara e professora do curso de Jornalismo da Universidade do Sagrado Coração (USC). E-mail: randrelo@usc.br

Até o início da década de 1990, com exceção das pessoas que tinham antena parabólica em casa, quem quisesse ver televisão poderia escolher entre sete canais abertos na freqüência VHF e mais alguns poucos em UHF. Com a consolidação da TV por assinatura, essa história mudou. No caso da TV a cabo, objeto deste estudo, o número de canais disponíveis aos assinantes varia, chegando a ser superior a cinqüenta.

Com esse grande rol de opções, é natural pensar que houve mudanças na forma da audiência se relacionar com o aparelho televisor. A partir do advento da TV a cabo, o controle remoto - ou mesmo o seletor de canais - passou a ser utilizado com mais freqüência. Para Hoineff, "O controle remoto, associado ao cabo, tornou o espectador mais ansioso"1.

Para mostrar como o cabo alterou a maneira pela qual o público assiste à televisão, Hoineff resgata a pesquisa publicada em setembro de 1988 pela revista Channels, de Nova York. De acordo com ela, 48,5\% dos telespectadores (portadores de controle remoto) mudam de canal durante um programa, embora 48\% achem menos agradável assistir à TV dessa forma. Outros 14,3\% entendem que é divertido mudar constantemente de canal.

Mais alguns dados referentes à pesquisa: entre os telespectadores que adotam a postura de mudar de canal durante um programa, 29,4\% justificam essa atitude dizendo que o programa estava aborrecido. Outros 28,4\% afirmam mudar de canal para "ter certeza de que não estão perdendo um programa melhor”2. Já 22,7\% mudam de canal para evitar os comerciais.

Dados mais atuais reforçam essa tendência dos telespectadores. Segundo pesquisa feita pelo Ibope Mídia, de 1993 a 2001, o número de casas com TV com controle remoto aumentou de $30 \%$ para $88 \%$. Já um levantamento feito pela MTV mostra que $73 \%$ do seu público muda de canal até durante o programa favorito ${ }^{3}$. 


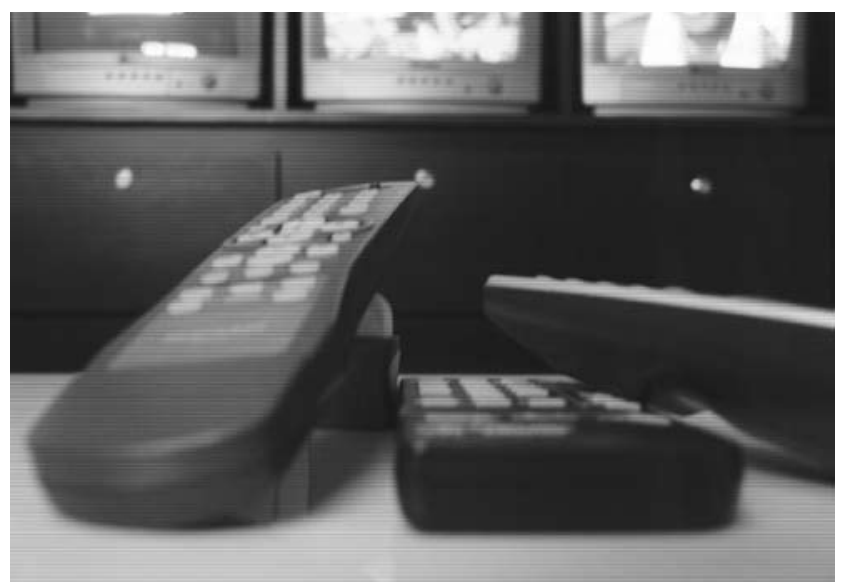

As facilidades do controle remoto, associadas à grande quantidade de canais, levam à prática do zapping.
Machado, que chama de zapping essa atitude de usar o controle remoto com freqüência, aponta que esse comportamento da audiência é uma preocupação bastante atual de quem trabalha com TV:

Os homens que financiam e fazem televisão se mostram cada vez mais preocupados com um fenômeno que assume hoje um significado especial: o zapping, ou seja, a mania de mudar de canal a qualquer pretexto, na menor queda de ritmo ou de interesse do programa e, sobretudo, quando entram os comerciais ${ }^{4}$.

Para Machado, o zapping intensificou-se com a proliferação e o aperfeiçoamento de aparelhos de TV com controle remoto. Porém, ele lembra que esse fenômeno já era conhecido na era do rádio, “(...) onde o controle remoto nunca chegou a vingar" ${ }^{\prime \prime}$.

"Hoje, as pesquisas de audiência trabalham com uma margem de erro e incerteza bastante preocupante, porque a constatação de que um telespectador está sintonizando, em determinado momento, um canal ' $x$ ' não garante que um minuto depois ele já não tenha evadido para outro canal. O telespectador está aprendendo a dominar criativamente a TV e a se vingar da mediocridade que nela se instala" ${ }^{\text {. }}$

O reconhecimento do zapping não coube apenas ao meio publicitário, mas também à academia. Barbero cita o aporte dos pós-modernos aos novos modos de leitura, que, nos Estados Unidos, principalmente, estão fundamentados no estudo do controle remoto da TV.

Esse leitor vagabundo, errante, nômade, que não fica quieto num só texto, mas que vai lendo ao mesmo tempo vários textos e, a partir deles, construindo outro texto. Ele parte de um informativo, de uma dramatização, fica fascinado com a publicidade, depois muda ${ }^{7}$.

Segundo matéria publicada pelo jornal Diário de Bauru, as emissoras de televisão têm desenvolvido estratégias para impedir a fuga de audiência nos intervalos. A reportagem aponta que, além de usar esses momentos para fazer outras coisas, como ir ao banheiro ou buscar uma bebida, o telespectador aproveita os
4. MACHADO, Arlindo. A arte do vídeo. 3. ed. São Paulo: Brasiliense, 1995. p. 113.

5. Ibid., p. 113.

6. Ibid.

7. SOUSA, Mauro Wilton de (Org.). Sujeito, o lado oculto do receptor. Tradução e transcrição de Sílvia Cristina Dotta e Kiel Pimenta. São Paulo: Brasiliense, 1995. p. 64. 
8. MARON, Alexandre. Proibido zapear. Diário de Bauru, Bauru, 12 set. 1999. p. 8.

9. BRAGA, José Luiz. Interação e Recepção. In: ENCONTRO ANUAL DA ASSOCIAÇÃO NACIONAL DE PROGRAMAS DE PÓS-GRADUAÇÃO EM COMUNICAÇÃO, 9 , 2000, Rio Grande do Sul. Anais eletrônicos. Rio Grande do Sul: PUCRS, 2000. 1 CD.

10. Ibid.

11. DIAS, Cláudia Augusto. Grupo focal: técnica de coleta de dados em pesquisas qualitativas. Informação e Sociedade. Paraíba, v. 10, n. 2, p.141158, 2000 intervalos para trocar de canal e ver o que mais está sendo exibido. "Nos jogos de futebol a oscilação da Globo no intervalo chega a ser de dez pontos no Ibope, o que significa cerca de 800 mil telespectadores só na Grande São Paulo" ${ }^{\text {. }}$

Com base em informações como essas e na tentativa de diminuir o que para elas é um problema, as emissoras adotaram algumas técnicas. Um exemplo é o fato de o apresentador de programas de auditório anunciar a atração que será mostrada no próximo bloco, na tentativa de prender a audiência. Situação parecida acontece com as novelas, cujos comerciais são exibidos em momentos importantes da trama, no clímax, de modo a garantir que a audiência se manterá até o retorno da atração.

Para Machado, vários motivos podem ser elencados como causa para o zapping: fuga dos comerciais, busca por um programa melhor, excesso de informações no ar ou o simples prazer em zapear. O uso contínuo do controle remoto também pode ser avaliado como uma resposta ao baixo nível de qualidade da programação televisiva.

Independente de qual motivo leva ao zapping - seja apenas um dos fatores ou o conjunto deles -, o que é sabido, de fato, é que o controle remoto fez com que os telespectadores não só deixassem de ser fiéis a um único canal, mas também parassem de assistir a programas inteiros.

\section{INTERATIVIDADE}

A prática do zapping demonstra uma forma de interatividade entre audiência e veículo de comunicação. A interatividade, contudo, não deve ser entendida como um modelo conversacional. Conforme relata Braga, uma vez que não há reciprocidade entre interlocutores, a interatividade midiática não é dialógica. Para ele, devese evitar caracterizá-la por essas lacunas, buscando suas próprias características.

Dentro dessa perspectiva, Braga entende que "se um componente do processo merece alguma centralidade, não seria o 'meio', mas o 'produto' real, concreto, historicamente elaborado e em elaboração, nas suas estruturas" . Ele acrescenta que o importante é como o produto circula na sociedade. "Nossa premissa básica é que, se um produto midiático é posto em circulação na sociedade, e efetivamente circula, há inevitavelmente interatividade"10.

A partir dessa visão, a mensagem difundida pelo veículo deixa de ser vista como algo pronto e acabado, mas na forma como circula na sociedade. $\mathrm{Ou}$ seja, ao fazer sua edição de imagens, o telespectador está recriando o conteúdo difundido pelos canais.

\section{PESQUISA COM A AUDIÊNCIA}

Para verificar se houve impacto na relação audiência-televisão a partir da implantação da TV a cabo, foi realizada uma pesquisa qualitativa, com a aplicação de um questionário e do grupo focal que, segundo S. Caplan ${ }^{11}$, é uma reunião de pequenos grupos de pessoas que avaliam conceitos ou identificam problemas. 
Uma vez que a opinião da audiência é fundamental para entender o ponto levantado, optou-se por aliar o questionário à discussão de grupo, devido à sua importância pelo aprofundamento de questões. Segundo Minayo,

O específico do grupo de discussão são as opiniões, relevâncias e valores dos entrevistados. Difere por isso da observação que focaliza mais o comportamento e as relações. Tem uma função complementar à observação participante e às entrevistas individuais ${ }^{12}$.

Com base nesses pressupostos, entre os assinantes da NET Bauru, operadora que oferece o serviço no município, dois grupos distintos foram selecionados para participar da pesquisa: um com adultos (acima de 18 anos) e outro com crianças e adolescentes (de 8 a 17 anos).

\section{DISCUSSÃO DOS RESULTADOS}

Mesmo que a televisão aberta continue líder de audiência entre os telespectadores adeptos de algum tipo de TV por assinatura, muita coisa mudou na situação de quase monopólio televisivo registrado até o início da década de 1990. Entre os participantes da entrevista de grupo focal, ficou claro que, de modo geral, os telespectadores não são mais fiéis a um ou dois canais, como eram antes.

Até há algum tempo, era comum deixar a televisão sempre no mesmo canal. Hoje, com a grande quantidade de opções, os telespectadores sentem-se curiosos - termo usado por alguns deles - para saber o que está passando nos canais. Quase todos os participantes da pesquisa disseram que escolhem o que ver pelo zapping, embora tenham decorado o horário de alguns dos seus programas favoritos.

Mais do que escolher o que assistir, ao controle remoto é atribuída uma outra função. Entre os participantes, alguns contam que utilizam o aparelho para mudar de canal freneticamente várias vezes, sem parar por muito tempo no mesmo canal. Um estudante universitário contou que muda de canal com freqüência mesmo que esteja gostando da programação. Essa postura demonstrada por grande parte dos adultos também foi registrada com a maioria dos participantes do grupo de adolescentes.

Entre os motivos que os fazem praticar o zapping, o que mais chama a atenção é a curiosidade de ver o que está sendo veiculado nos outros canais. Para muitos, vale a pena mudar e verificar se não estão perdendo nada interessante, mesmo que já tenham encontrado algo de que gostem. Os outros motivos alegados são: programação ruim e intervalo comercial. Antes da assinatura da TV a cabo, os participantes contaram que zapeavam menos, porque havia menos opções.

Essa curiosidade também faz com que muitos telespectadores assistam a mais de um canal ao mesmo tempo. Um web designer de 23 anos contou que chega a assistir três programas simultaneamente. Um universitário de 21 anos disse que "assiste a tudo ao mesmo tempo". Os zapeadores reconhecem que é desagradável assistir à TV ao lado de alguém que tem o mesmo hábito de mudar de canal freneticamente.

Com tantas opções na televisão e com a prática do zapping, fica difícil imaginar o aparelho televisor sem o controle remoto. Um atleta de 20 anos disse
12. MINAYO, Maria Cecília de Souza. O desafio do conhecimento: pesquisa qualitativa em saúde. 6. ed. São Paulo: Hucitec; Rio de Janeiro: Abrasco, 1999. p. 129. 
que ficou desesperado quando o dele quebrou. Além disso, tanto os adolescentes quanto os adultos contaram que chega a haver disputa, dentro de casa, para ver quem fica com o controle na mão.

\section{FRAGMENTAÇÃO DA CONSCIÊNCIA}

O presente trabalho procura mostrar como a audiência tem interagido com a TV a cabo e as alterações que essa tecnologia gerou no conceito tradicional de televisão. Não se trata de supervalorizar o poder tecnológico, mas de reconhecer que essas mudanças necessariamente implicariam uma nova maneira de assistir à televisão.

Sabe-se, contudo, que a tecnologia do cabo, por si só, não geraria sozinha essa nova forma de ver TV. Embora a cotidianidade tenha papel central nas análises, não se pode desprezar o contexto tecnológico em que a televisão está inserida. Entre os participantes que contaram assistir à TV mudando de canais freneticamente, muitos disseram fazer o mesmo quando estão com o computador conectado à internet.

A interatividade destaca-se como o traço característico das novas audiências, parecendo resultar das possibilidades técnicas oferecidas pelos novos meios e induzindo a condutas fragmentárias ou intermitentes. As facilidades do controle remoto, associadas à grande quantidade de canais, aparecem nas discussões diretamente relacionadas à prática do zapping. Segundo as respostas dos participantes, não se trata mais apenas de mudar de canal na hora dos anúncios publicitários ou quando a programação é considerada pouco atraente. Muda-se de canal a todo instante, muitas vezes sem que haja um motivo convincente para isso. Apertar os botões do controle remoto, para alguns telespectadores, virou um hábito.

Seria preciso investigar até que ponto essas novas condutas não estão relacionadas a uma consciência também fragmentada da realidade. Nesse sentido, é importante comparar a atitude diante do livro (rejeitado pela falta de paciência, segundo respostas colhidas no grupo focal) com a adesão à leveza do zapping, que não se fixa em nenhum ponto específico, de modo que não pode gerar um conhecimento - qualquer que seja - completo sobre determinado tema ou programa.

Com essa prática, há uma interação com a televisão, que não é direta nem sequer democrática, a ponto de dizer que a audiência escolhe o que vai ser mostrado na TV. Mas, ao mesmo tempo que recebem uma programação pronta, os telespectadores montam seu programa. Ao passear pelos canais, fazem uma colagem que inclui vários gêneros televisivos. Trata-se de algo tão pessoal, que todos admitem que só quem está de posse do controle remoto consegue assistir.

Não há como negar que o zapping é uma forma de interação da audiência com a TV e uma forma de não mais aceitar tudo pronto. Também é possível imaginar que, apenas com os poucos canais da TV aberta, essa prática não teria o mesmo sentido. Para o diretor-geral da MTV, André Mantovani, o zapping tende a aumentar quando mais pessoas tiverem TV a cabo ${ }^{13}$. A postura inquieta de muitos telespectadores mudou a forma como vêem TV, mas também acarretou

mudanças no modo como a programação é pensada.

controlar controle remoto, op. cit. 
Segundo o Ibope ${ }^{14}$, o zapping ajuda na pulverização da audiência entre os canais e também na diminuição do tempo em que o telespectador permanece assistindo a uma mesma programação. "O mercado se assustou com as conseqüências do zapping, mas o fenômeno acabou empurrando nossa TV para uma evolução"15, avalia o publicitário Luiz Lara, da agência Lew,Lara.

Entre essas mudanças, constam intervalos mais bem planejados, em menor quantidade, mais curtos e interativos. "O comercial tem de fisgar o público com emoção ou humor. O telespectador tem de senti-lo como parte da programação. Só assim evitamos que ele mude de canal"16, acrescenta Lara. "A dinâmica das atrações não é mais a mesma: o número de estímulos visuais e de informação não é o mesmo, o público é como camaleão, muda a todo momento e quer que seu veículo de comunicação mude também"17.

Ao mesmo tempo que o zapping demonstra a insatisfação da audiência e o fato de os produtores de TV e os publicitários estarem preocupados com isso ser bastante significativo, cabe questionar qual o resultado dessa colagem visual para o telespectador. Conforme discutido, o resultado pode ser algo totalmente inovador, como também pode levar à “[...] reiteração infinita e pleonástica do mesmo enunciado"18.

De acordo com respostas dos participantes do grupo focal, é possível supor que a prática do zapping torna a TV um objeto ainda mais de entretenimento e menos de fonte de informação. A maioria dos participantes da pesquisa afirmou que a partir da assinatura da TV a cabo passou a assistir mais à televisão. A melhora na qualidade do sinal e o aumento no número de opções foram os dois principais motivos para que deixassem outras atividades de lado em nome da programação televisiva. Eles contam que, quando estão em casa, a TV só é desligada, praticamente, na hora de dormir.

Resumo: O presente trabalho discute a interatividade da audiência com a televisão a partir da tecnologia da TV a cabo. O grande número de canais aliado ao controle remoto deixou o telespectador mais ansioso. Com base no resultado de uma pesquisa qualitativa, feita com a técnica de grupo focal, e nos depoimentos de profissionais que trabalham com televisão, percebe-se que parte da audiência deixou de assistir a programas inteiros e passou a passear pelos vários canais sem se prender a nenhum deles. Este artigo mostra que a interatividade se destaca como traço característico da audiência, parecendo resultar das possibilidades técnicas oferecidas pelos novos meios e induzindo a condutas fragmentárias ou intermitentes.

Palavras-chave: TV a cabo, interatividade, estudo da audiência, zapping, controle remoto.
Abstract: This article discusses the interactivity between $\mathrm{TV}$ and its public, from cable broadcasting system. It shows that the vast number of channels plus the remote control usage have made audience more anxious. Based on a qualitative research (through interviews in a specific group) and on statements from TV professionals, it could be noticed that part of the audience gave up watching the whole program and started to zap. This study shows that interactivity is in evidence in today audiences probably caused by the offering of new technology conveniences that leads to fragmental and intermittent audience performance.

Keywords: cable TV, interactivity, audience study, remote control.

14. Ibid.
15. Ibid.
16. Ibid.
17. Ibid.
18. MACHADO, Arlindo.
Máquina e imaginário: o
desafio das poéticas tec-
nológicas. 2. ed. São Pau-
lo: Edusp, 1996. p. 146. 